\title{
Eco-efficient biorefineries: Techno-fix for resource constraints?
}

\section{Les Levidow}

\section{(2) OpenEdition}

1 Journals

\section{Édition électronique}

URL : http://journals.openedition.org/economierurale/4729

DOI : $10.4000 /$ economierurale. 4729

ISSN : 2105-2581

\section{Éditeur}

Société Française d'Économie Rurale (SFER)

\section{Édition imprimée}

Date de publication : 15 décembre 2015

ISSN : 0013-0559

\section{Référence électronique}

Les Levidow, «Eco-efficient biorefineries: Techno-fix for resource constraints? », Économie rurale [En ligne], 349-350 | septembre-novembre 2015, mis en ligne le 15 décembre 2017, consulté le 02 mai 2019. URL : http://journals.openedition.org/economierurale/4729 ; DOI : 10.4000/ economierurale. 4729

Ce document a été généré automatiquement le 2 mai 2019.

(c) Tous droits réservés 


\title{
Eco-efficient biorefineries: Techno- fix for resource constraints?
}

\author{
Les Levidow
}

\section{NOTE DE L'AUTEUR}

Acknowledgements: Some research leading to these results has received funding from the European Community's Seventh Framework Programme under grant agreement $\mathrm{n}^{\circ}$ 217647, entitled 'Co-operative Research on Environmental Problems in Europe' (CREPE) during 2008-10. Thanks to participants' comments in the biorefineries session at the 2014 conference of the European Society for Ecological Economics (ESEE). For helpful comments on an earlier draft of this paper, thanks to the journal's two reviewers and Rachel Smolker.

\section{Introduction}

1 A future bioeconomy has been widely promoted as crucial means to alleviate constraints of rising global demand for natural resources. Policy and industrial agendas together envisage biorefineries which could more efficiently convert renewable biomass, preferably non-food material and bio-waste. Its conversion would yield diverse products plus energy, thus substituting for fossil fuels.

2 For such conversion, a biorefinery is 'the sustainable processing of biomass into a spectrum of marketable products', as defined by the International Energy Agency (IEA, 2014). It would be made sustainable by technoscientific advance: Given 'the growing demand for food, energy and water... only the use of new technologies will allow us to bridge the gap between economic growth and environmental sustainability in the long run' (WEF, 2010). Contrary to such claims for future benefits, skeptics have anticipated various harms from expanding biorefineries. 
3 Starting from such debates, this review paper investigates assumptions and economicpolitical drivers of biorefinery priorities. This builds on a study of the EU's bioeconomy agenda during 2008-10 (see Acknowledgements section). This earlier study asked interviewees numerous questions such as, 'How does the bioeconomy change the role and meaning of agriculture?', and 'How does technoscientific advance depend upon wider societal changes?' Interviewees encompassed EU-level research managers and stakeholders from industry, farmers and NGOs. As the analysis showed, a future European bioeconomy has divergent trajectories - based either on Life Sciences or else on agroecology (Levidow et al., 2012, 2013).

This paper investigates further the Life Sciences trajectory of future biorefineries - their preconditions, assumptions and implications. It draws on a follow-up analysis of documents from the US and well as the EU contexts. Sources encompass government agencies, expert bodies and various stakeholder groups; see the Box for a list of organisational abbreviations.

5 It discusses the following questions:

- What drives state and industry bodies to promote biorefinery development?

- On what assumptions can future biorefineries alleviate resource constraints and their sustainability problems?

- How do those assumptions relate to the current causes of resource-sustainability problems?

- What wider role is played by a policy vision for future biorefineries?

6 The paper is structured by five main sections: 1) sustainability claims and doubts around future biorefineries; 2\&3) debates over such issues in the US and EU, respectively; 4) critical perspectives from Science and Technology Studies (STS) and human geography, e.g. socio-technical imaginaries, the techno-fix as a performative device, the rebound effect and capital accumulation by dispossession; and 5) conclusion answering the above questions.

7

[Box]

Organisational Sources of Documents

Each body is followed by a self-description, with no comment on its claims.

Global bodies

GFC: Global Forest Coalition, an international coalition of NGOs and indigenous peoples' organizations defending social justice and the rights of forest peoples in forest policies.

IAE: International Energy Agency, an autonomous organisation which works to ensure reliable, affordable and clean energy for its 29 member countries and beyond.

UNEP: United Nations Environment Programme, the leading global environmental authority that sets the global environmental agenda.

WEF: World Economic Forum, the international institution for public-private cooperation to shape the global, regional, national and industry agendas; holds annual meetings in Davos.

US context

EIA: US Energy Information Administration collects, analyzes, and disseminates independent and impartial energy information to promote sound policymaking, efficient markets, and public understanding of energy and its interaction with the economy and the environment.

NABC: North American Agricultural Biotechnology Council addresses the central 
questions of agricultural biotechnology from a multi-constituency perspective; members are research institutions involved in activities that support agricultural biotechnology research and development.

USDA: United States Department of Agriculture provides leadership on food, agriculture, natural resources, rural development, nutrition, and related issues based on public policy, the best available science, and effective management.

US DoE: US Department of Energy is a governmental department aiming to advance energy technology and promote related innovation in the United States.

USFS: US Forest Service aims to sustain the health, diversity, and productivity of the nation's forests and grasslands to meet the needs of present and future generations.

EU context

AEA Technology: a UK consultancy dealing with energy, climate change and data management issues.

BBI Consortium: Bio-Based Industries Consortium, the private-sector partner in the European Public-Private Partnership on Bio-based Industries (BBI).

bio-economy.net: joint website of Europabio and ESAB (European Federation of Biotechnology Section on Applied Biocatalysis).

Biofrac: Biofuel Research Advisory Council (until 2006), predecessor of the EBTP.

BioMatNet: Biological Materials for Non-Food Products. Information database from ECsupported projects concerning the development of renewable bioproducts and biofuels.

CEC: Commission of the European Communities, executive policy-making and budgetary body of the European Union.

DSCR: Danish Council for Strategic Research funds research aiming at finding solutions to challenges facing Danish society; led a bioeconomy report for an EU-wide conference.

EBTP: European Biofuels Technology Platform aims to contribute to the development of cost-competitive world-class biofuels value chains and the creation of a healthy biofuels industry, and to accelerate the sustainable deployment of biofuels in the European Union, through a process of guidance, prioritisation and promotion of research, technology development and demonstration.

EPOBIO: an international project of 'Science to Support Policy', funded by the European Commission in the Sixth Framework Programme (approx. 2002-2006) and with the cooperation of USDA.

EuropaBio: European Association for Bioindustries aims to promote an innovative and dynamic biotechnology base in Europe; membership includes a wide range of corporate members and industry associations involved in biotechnology throughout Europe.

\section{Promoting eco-efficient biorefineries}

Given the global conflict between resource demands versus environmental sustainability, solutions are being sought through biorefineries in a bioeconomy perspective. This section analyses the corporate vision for novel biofuels (and other industrial products), their commercial drivers and prospects to lower resource burdens. How do the drivers relate to innovation priorities and sustainability implications? A political-economic imperative to avoid structural change directs R\&D towards input substitutes, thus limiting the prospects for sustainability, as this section argues. 


\section{Extending agro-industry for biorefinery feedstocks}

9 Biofuels have substituted renewable biomass for fossil fuels. But biofuels generally cannot compete economically with oil and so have depended on mandatory quotas and/or subsidy, officially justified by various societal benefits. But the putative benefits were apparently contradicted - by displacement or diversion of food crops, land grabs, environmentally harmful cultivation methods, intensified forest management, waste byproducts and dubious savings in greenhouse gas (GHG) emissions. NGO networks highlighted such harm in 2007-2008, especially as a basis to oppose the EU's biofuel targets for 2020 (Econexus et al., 2007). Their intervention provoked controversy over criteria and prospects for truly 'sustainable biofuels' (Franco et al., 2010; Levidow, 2013; Searchinger et al., 2008; Söderberga and Eckerberg, 2013; TU-E/NWO, 2015).

Partly in response to the controversy, conventional biofuels were retrospectively renamed 'first generation', as if they were a temporary stage towards the next generation. For second-generation biofuels, the feedstock was envisaged as non-food parts of plants, e.g. post-harvest residues in agricultural fields and forests, or non-food plants such as grasses, ideally cultivated on 'marginal land'. These future fuels are meant to use resources that are otherwise under-utilized or undervalued, especially waste and surplus land, as a basis to avoid land-use competition with food production (DCSR, 2012; Europabio, 2007; IAE, 2010; numerous sources cited in Levidow and Paul, 2011).

11 Relative to conventional biofuels, second-generation ones are even less economically viable, though costs could be lowered by various means - e.g., technology improvement, higher conversion efficiencies and better transport logistics', according to an expert report (IAE, 2010). Their prospects for greater sustainability will be contingent on specific circumstances:

Depending on the feedstock choice and the cultivation technique, secondgeneration biofuel production has the potential to provide benefits such as consuming waste residues and making use of abandoned land. In this way, the new fuels could offer considerable potential to promote rural development and improve economic conditions in emerging and developing regions. However, while secondgeneration biofuel crops and production technologies are more efficient, their production could become unsustainable if they compete with food crops for available land. Thus, their sustainability will depend on whether producers comply with criteria like minimum lifecycle GHG reductions, including land use change, and social standards. (ibid.).

In a future vision for biofuels and beyond, a biorefinery will more efficiently break down the plant cells' key components (starch, cellulose and hemicellulose) to obtain the building blocks of the chemical industry, generally pursuing a one-to-one substitution strategy. Within an agro-industrial bioeconomy vision, plant resources are being redesigned as more flexible biomass, through easier decomposition and recomposition into various industrial products (sources cited in Levidow et al., 2013a).

Such flexibility was anticipated by an international research network funded by the US and EU. It aimed to design new generations of bio-based products derived from plant raw materials (EPOBIO, 2006). Its bioeconomy vision would change the role of agriculture, which becomes analogous to oil wells: 'It was noted by DOE and EU that both the US and EU have a common goal: Agriculture in the 21st century will become the oil wells of the 
future - providing fuels, chemicals and products for a global community' (BioMat Net, 2006).

Towards future biorefineries, research seeks more efficient techniques for converting biomass to cellulosic bioethanol and other industrial products, while also expanding opportunities for proprietary knowledge, as envisaged in an OECD report (Murphy et al., 2007). Patents have been obtained or are expected for components at several stages (Carolan, 2009). Indeed, the search for intellectual property 'has a strong influence on science', according to a trans-Atlantic expert network on the bioeconomy (EC-US Task Force, 2009).

This biorefinery vision naturalises changes in future markets and land use, as expressed in a major report by the World Economic Forum. Here future rises in market demand appear simply as objective force - an 'exponentially increasing demand' for raw materials - as if this were exogenous to the industrial sectors fulfilling and stimulating the demand. This 'may shift the relative economics of food/feed production vs other land uses, such as cellulosic energy crops' (WEF, 2010). This shift is implicitly attributed to the invisible hand of the market, while also demanding policy support: governments must 'support significant investments in R\&D technology by creating markets...' (WEF, 2010).

Biorefinery promoters seek input-substitutes for oil in order to maintain the capital value of previous infrastructural investment - against threats of truly novel systems. In particular, 'the automotive industry is currently most concerned with the threat posed by non-fuel propulsion systems', e.g. hydrogen cells. This threat has been 'giving focus to the development of new fuel technology that may allow these to continue to dominate the automotive industry' (ibid.). As a key priority, 'drop-in' fuels would provide exact substitutes for petrol within current infrastructure, thus maintaining its investment value while portraying it as a 'low-carbon' system (Birch and Calvert, 2015; Levidow and Papaioannou, 2013; Levidow et al., 2013b). This political-economic imperative to avoid structural change drives R\&D towards input substitutes, partly by redesigning organisms and conversion techniques. The global biorefinery agenda seeks more flexible inputsources, increasing the power of processors over suppliers near the bottom of the value chain (Borras et al., 2015).

17 Fulfilling the future market demand will depend on further integrating value chains, argues the expert report:

The newly established value chain will have room for non-traditional partnerships: grain processors integrating forward, chemical companies integrating backwards, and technology companies with access to key technologies, such as enzymes and microbial cell factories joining them (WEF: 20).

18 Through such vertical integration, the global South will have greater business opportunities to supply raw materials:

... a new international division of labour in agriculture is likely to emerge between countries with large tracts of arable land - and thus a likely exporter of biomass or densified derivatives - versus countries with smaller amounts of arable land (ibid.)

In particular Africa has a great economic opportunity but faces several challenges:

One is their low agricultural productivity caused by suboptimal agricultural practices, such as lack of fertilizers, deficient crop protection, shortcomings in the education and know-how of farm workers, insufficient irrigation and the dominance of smallholder subsistence farming (ibid.). 
expressed less euphemistically, Africa must weaken peasants' land-tenure to replace their agriculture systems with chemical-intensive agro-industrial plantations, as a prerequisite to supply feedstock for biorefineries. This political-economic driver limits the prospects for environmental sustainability and local livelihoods, as next illustrated by resource burdens.

\section{Driving water demand and pollution?}

21 Alongside harmful changes in land-use, biofuel production has already used and polluted greater flows of water, thus undermining other land uses. This experience generated debate over implications of converting more biomass as an oil substitute. For bioenergy in general, a UNEP expert report highlighted the water issues, which have wider relevance: 'most of the concerns raised in this report are not unique to bioenergy, but are examples of larger, systemic issues in agriculture, industry, land use and natural resource management' (UNEP et al., 2011).

Biofuels consume much more water than fossil fuels, especially when the feedstock comes from irrigated crops (ibid.). As the report suggests

,... biofuels are very water-intensive relative to other energy carriers. This increased water demand can place considerable stress on available water supplies. Similarly, little attention has been paid to the opportunities that bioenergy may present for adaptation to water constraints. New drought-tolerant plant types could be cultivated as biofuel feedstock, and might be integrated with food and forestry production in ways that improve overall resource management... (UNEP et al., 2011).

Also beneficial would be: cultivating rain-fed crops on marginal land, or shifting land use from arable crops to perennial woody crops, argues the report (ibid: 15, 44). It is silent about the incentives that would favour such practices over more profitable ones, e.g. cultivating and industrialising the most fertile land, clearing forests or turning them into plantations, thus maximising production of commodity crops.

Moreover, the term 'marginal' is deceptive, concealing the important role of land and its resources for local livelihoods: An area can be seen as grassland, and therefore marginal, even though it may well be part of a traditional way of farming with or part of pastoralists' seasonal herding practices, or a space valued as a buffer zone. It may have a particular cultural or ecological significance... [however] State-centric land-use classifications - such as 'marginal lands', 'empty lands' and so on - have become the defining concepts in development processes, whether or not they have any basis in reality (Borras and Franco, 2012).

Alongside competing uses or meanings of land, biomass cultivation and processing impose great burdens on natural resources. For example, maize-based biofuel refineries produce 13 litres of waste water for each litre of ethanol. The nitrogen applied as fertilizer (now 45 million $\mathrm{t} / \mathrm{a}$ ) has not only doubled the natural volume of the nitrogen cycle, but also evaporates in particular from tropical agriculture as $\mathrm{N} 2 \mathrm{O}$, a greenhouse gas 300 times as harmful as $\mathrm{CO}$. Besides the water used in agricultural cultivation, additional demand comes from the refining process, waste and waste water treatment, distribution systems, etc. (Spangenberg and Settele, 2009).

At the cultivation stage, water supply remains a serious problem even in the metabolically more efficient, faster C4 plants (e.g. maize, grasses, sugarcane, sorghum). 
These are cultivated mainly in tropical regions; their optimal growth temperature is between $30-45^{\circ} \mathrm{C}$. By contrast $\mathrm{C} 3$ plants function between $15-25^{\circ} \mathrm{C}$. Nevertheless to produce $1 \mathrm{~kg}$ of dry biomass, $\mathrm{C} 4$ plants still need 230-250 litres of water - either from rain, from ground water or from irrigation. Comprising most crops, $\mathrm{C} 3$ plants need 2-3 times as much water. (The two categories differ in enzymatic pathway for $\mathrm{CO} 2$ conversion.) In both pathways, one molecule of water is consumed for each molecule of carbon dioxide fixed.. According to critics, 'these high-yielding plants, in order to realize their potentials, are dependent on intensive, large-scale, mostly monoculture agriculture or forestry' (Spangenberg and Settele, 2009).

Some biofuels are accompanied by co-products, which potentially offer economic benefits from extra income and environmental benefits from substitution for oil. As a basis to account for 'avoided water use', the UNEP report optimistically assumes that co-products always substitute for production elsewhere (UNEP et al., 2011). Yet they more plausibly supplement it, thus expanding global markets. Regardless of that outcome, the processing pollutes water:

The main sources of pollution are clearly related to the use of pesticides and fertilizers, but also to certain co-products (e.g. vinasse) from the industrial pathways of some feedstocks. The impacts of these co-products on water quality depend upon several natural factors, as well as on the severity of the impacts and their effects, including indirect and cumulative ones (ibid.).

Further to that example, biomass cultivation and processing degrades water supplies. In Brazil's bioethanol production, sugar cane processing creates environmental problems, such as waste water depleting oxygen in water systems. Each litre of ethanol generates 12 litres of bagasse, a red-acid fluid with a high oxygen demand in waste-water treatment, as well as causing air pollution from sugar cane straw incineration. The harm extends beyond the plantations, for instance through the deterioration of wetlands, streams, rivers and reservoirs by silt and sediment, loaded with polluting chemicals (Martinelli and Filoso, 2008).

If biorefineries allow food inputs to be replaced with non-edible feedstocks, then will this alleviate resource burdens? According to an expert study on countries in the global South, freshwater supply is an increasing problem, so priority should be given to 'feedstock sources like agricultural and forestry residues that do not require irrigation'. And the removal of primary residues, e.g. straw, 'could lead to nutrient extraction that has to be balanced with synthetic fertilisers to avoid decreasing productivity' (IEA, 2010). Resource constraints and environmental burdens continue, regardless of the specific feedstock.

The next two sections look at how those sustainability issues have arisen in debates over future biorefineries in the US and EU, respectively. The US agenda has focused on more efficiently using domestic biomass for lowering dependence on oil. By contrast, with a broader ambition, the EU agenda seeks to make biomass a more flexible input for integrating industrial sectors.

\section{US debate over future biorefineries}

In the name of energy independence, the US government has promoted corn (maize) bioethanol through various policies - renewable fuel standards, tax credits, loans, ethanol-import tariffs, etc.Yet maize-based bioethanol has been widely criticised as 
unsustainable, both financially and environmentally. Such criticisms stimulated a biorefinery vision: technoscientific advance would more efficiently convert lignocellulosic feedstock, avoid competition with food biomass and provide a more costeffective method of biofuel production (Congressional Budget Office, 2010: 7). In this vision, moreover, the biorefinery co-product (DDGS) would substitute for conventional animal feed, whose production normally depends on petroleum-based grains. In such ways, US biorefinery innovation has envisaged more efficient ways of using domestic biomass to lower national dependence on oil. This section analyses assumptions, drivers and sustainability implications of the US vision.

\section{Benignly replacing oil?}

Debates over a future bioeconomy were prefigured in early exchanges among experts. As the Cold War ended, 'security' agendas expanded to conflicts over natural resources, especially oil imports. According to a former CIA Director, a bio-based economy would lower import costs and enhance energy security: a rational approach is to substitute biofuels from locally grown materials, especially cellulosic biomass (NABC, 2000). Although accepting that this vision could be beneficial, the consumer rights advocate Ralph Nader warned that any technology can be used to concentrate power; this could extend farmers' integration into contract arrangements with little bargaining power (NABC, 2000).

To realise the vision of cellulosic fuels, the US government has funded R\&D for novel biorefineries. From its mandate in the Energy Policy Act 2005, the Department of Energy has funded several components and pathways, especially for cellulosic bioethanol, given the abundance of waste cellulose from agriculture. Its more efficient conversion warrants horizontal integration: 'A robust fusion of the agricultural, industrial biotechnology, and energy industries can create a new strategic national capability for energy independence and climate protection' (US DoE, 2006). Research topics include genomics research that will improve biomass characteristics, biomass yield, or sustainability, and novel microbial systems that can increase bioconversion efficiency and thus lower biofuel cost (US DoE, n.d.).

Such R\&D gained a further boost from the Energy Independence and Security Act 2007, which requires that 16 billion gallons of US transportation fuel be cellulosic biofuel by 2022. This requirement was expected to stimulate cellulosic biofuel patents, especially for biodiesel (Kamis and Joshi, 2008). To promote such innovation, in 2009 the US government announced $\$ 800 \mathrm{~m}$ economic stimulus funding for research into secondgeneration biofuels made from non-food crops such as grasses and algae, as well as $\$ 1.1 \mathrm{bn}$ in new financing for commercial development, e.g. for biorefineries and related infrastructure. Meanwhile subsidy for all biomass feedstock continued: During 2013 biomass producers benefited from $\$ 629 \mathrm{~m}$ in support, including $\$ 332 \mathrm{~m}$ in direct expenditures, $\$ 46 \mathrm{~m}$ in tax expenditures and $\$ 251 \mathrm{~m}$ in R\&D (EIA, 2015). Research encompasses numerous approaches to redesign crops for their interactions with soil microbes, as means to enhance the extraction of dry biomass while minimising nutrient loss to soil (US DoE, 2015.

Although R\&D prioritises conversion of non-edible biomass, even its usage will impose resource burdens. When former President George W. Bush warned against 'oil addiction' in his 2006 State of the Union speech, he mentioned switchgrass as a long-term solution 
beyond corn bioethanol. This option provoked warnings from NGOs and scientists: switchgrass normally helps to sequester carbon, preserve soil fertility, and conserve wildlife on set-aside land, so these benefits would be undermined by large-scale harvesting for biofuels.

Another potential feedstock for future biofuels, crop residues, are normally tilled back into the soil after harvest. This replenishment is necessary to maintain soil health as well as to avoid soil erosion in 'no till' cultivation; so such benefits could be undermined by removing residues for biorefineries, argue numerous critics (e.g. Tokar, 2010). Likewise, 'Removing corn stover or other agricultural residues means soils get more compacted and less organic matter is recycled back into the soils, which are also left more exposed to erosion' (Smolker, 2014). According to the Global Forest Coalition,

Crop residues left to decompose in agricultural soils are an important means of regenerating and stabilizing soils. Removing them, even a portion, will decrease the soil organic content, alter soil texture, increase erosion, decrease water retention, and lead to an overall decline in productivity and further degradation of agricultural soils (GFC, 2008).

Also contentious are water demands on the production process. US experts warned that biofuel production already puts extra pressures on natural resources, especially water. For conventional biofuels, 4 gallons of water are needed to produce 1 gallon of ethanol far more than the water needed for petroleum processing. Moreover, 'In the longer term, the likely expansion of cellulosic biofuel production has the potential to further increase the demand for water resources in many parts of the United States,' though this is difficult to predict, according to an expert report ( US NAS, 2007). To displace just onequarter of US gasoline usage, 'Even cellulosic ethanol would require 146 gallons of water per gallon and 35 percent of the [US] cropland (Geis, 2010).

Industry plans to intensify forestry for biomass harvesting. This means turning forests into monoculture plantations, especially in the southeastern US, which already has a large woodchip export to Europe. Industry also seeks more biomass from 'thinning and restoration', especially in western states.

US foresters have warned against such plans: 'bioenergy use...and invasive species will significantly alter the South's forests between 2010 and 2060... 23 million acres of forest are projected to decrease'. They anticipate lower water availability, resulting in more frequent and severe wildfires (USFS, 2011). ArborGen's genetically modified (GM) eucalyptus has been field-tested in the southeastern USA; approval for commercial use is expected. Yet the US Forest Service anticipates that eucalyptus plantations would use twice as much water as native forests and would reduce stream flow $20 \%$ more than existing pine plantations (USDA Final Environmental Assessment, 2010).

Conventional trees already were causing environmental problems, so the prospect of GM eucalyptus became even more contentious:

We are also concerned about the potential impacts of eucalyptus plantations on other ecosystem processes, including fire frequency and intensity. The leaves of eucalyptus trees produce large amounts of volatile oils... consequently, dense eucalyptus plantations are subject to catastrophic firestorms. The eucalyptus trees will lower water tables and decrease ground moisture... increasing the chance of wildfire ignition (Georgia Dept of Natural Resources, 2010).

41 The Union of Concerned Scientists warned that novel biofuels could extend the current harm from conventional biofuels, especially by depleting water and soil: 
As cellulosic biofuels production grows to a scale of billions of gallons a year, demand for feedstocks like energy crops will start to compete with food and feed production for scarce agricultural resources i.e., fertile land, water, and nutrients (Martin, 2010). manure containing high levels of nitrogen and phosphorous; this contributes to high NO2 emissions, thus undermining GHG savings. After being fed DDGS, moreover, many cows suffered E.coli infections (Shattuck, 2008). DDGS has a high sulphur content which causes neurological disease in livestock. DDGS is difficult for livestock to digest, sometimes resulting in gastrointestinal illness and even human illness from E.coli in contaminated meat. chemicals - whose residues end up in DDGS. This aggravates the long-standing problem of livestock production generating antibiotic-resistant bacteria. After the US FDA found antibiotic residues in DDGS samples taken from ethanol plants in 2008, it required prior 
approval of antibiotics as 'food additives' before they can be used there. But the FDA failed to enforce its own rule, even after several years (Olmstead, 2009, 2012).

Thus DDGS production contributes to the more general threat of food degradation and antibiotic resistance undermining therapeutic use. Claims for GHG savings depend on overly optimistic assumptions about benign substitution for animal feed, as if plant products were flexibly interchangeable. Despite the harmful effects and dubious safety assumptions, there are efforts to use DDGS for pig, poultry, pet and even human food.

\section{EU debate over future biorefineries}

49 EU bioeconomy agendas have aimed to facilitate new market opportunities for novel techniques and products, alongside lower resource burdens. At the 2007 Cologne Summit of the European Council, its President declared, 'Europe has to take the right measures now and to allocate the appropriate resources to catch up and take a leading position in the race to the Knowledge-Based Bio-Economy', henceforth called the KBBE (EU Presidency, 2007). Likewise when the Belgian Presidency hosted a follow-up conference on the KBBE, the DG Research Commissioner stated: 'Today, Europe has a strong life sciences and biotechnology research base to support the development of a sustainable and smart Bio-Economy' (Geoghegan-Quinn, 2010). This section investigates assumptions, drivers and sustainability implications of the $\mathrm{EU}$ vision.

\section{Integrating industrial sectors}

As a sustainability rationale for biorefineries, they will help society to 'live within its limits' through renewable resources and their more efficient use (Geoghegan-Quinn, 2012). Yet such visions stretch any limits through techno-optimistic assumptions about a resource cornucopia, as in the Declaration of an EU Presidency conference:

The perceived conflict between food and non-food production from arable land could be overcome by using agricultural crop and forestry residues and biodegradable waste as well as selecting feedstock such as algae and other underexploited resources from aquatic and marine environments, and by using existing and new knowledge and technologies to increase biomass yield (DCSR, 2012).

51 Industry seeks a flexible horizontal integration, diversifying biomass sources and its potential uses (www.bio-economy.net). As a primary means to extract and recompose valuable substances through a biorefinery, 'Biotechnology has the potential greatly to improve the production efficiency and the composition of crops and make feedstocks that better fit industrial needs' (EPOBIO, 2006). By enhancing biomass decomposability, this agenda links major agricultural industries - e.g., seed, fertilizer, pesticide, commodities and biotechnology - with the energy sector, including the oil, power, and automotive industries. To formulate R\&D agendas, the European Commission initially funded various technology platforms - for biofuels, plants, food, animal breeding, etc.

In an early rationale for the EU to fund biorefinery R\&D, second-generation biofuels were expected to 'boost innovation and maintain Europe's competitive position in the renewable energy sector', according to the European Commission (CEC, 2007). In its view, 'long-term market-based policy mechanisms could help achieve economies of scale and stimulate investment in "second generation" technologies which could be more cost effective' (CEC, 2006). 

reasons. This opens up links with other industries and export markets, as well as a potential basis for multiplying value chains. It also accommodates the existing transport infrastructure, locked into liquid fuel technologies, according to the European Biofuels Technology Platform (EBTP, 2008: SRA-1). Likewise the vehicle industry seeks 'drop-in' fuels as substitutes within current infrastructure for liquid fuel, thus minimising the future extra demand for oil (Levidow et al., 2013b).

Looking beyond biofuels, the European Biofuels Technology Platform develops strategies to optimize valuable products from novel inputs. It requests funds to 'develop new trees and other plant species chosen as energy and/or fiber sources, including plantations connected to biorefineries'. For advanced biofuels, a biorefinery needs: 'Ability to process a wide range of sustainable feedstocks while ensuring energy and carbon efficient process and selectivity towards higher added value products', e.g., specialty chemicals from novel inputs (EBTP, 2008: SRA-23). Such R\&D agendas facilitate and drive land-use change towards agro-industrial plantations.

ore ambitiously, the 'integrated diversified biorefinery' has been envisaged to diversify inputs and outputs, especially through novel enzymes and processing methods, generating diverse by-products including biofuels:

the integrated diversified biorefinery - an integrated cluster of industries, using a variety of different technologies to produce chemicals, materials, biofuels and power from biomass raw materials agriculture - will be a key element in the future. And although the current renewable feedstocks are typically wood, starch and sugar, in future more complex by-products such as straw and even agricultural residues and households waste could be converted into a wide range of end products, including biofuels (EuropaBio, 2007).

This seeks horizontal integration of agriculture with the oil, chemical and transport industries, thus optimizing the market value of resources and intellectual property. Inputs and outputs can be flexibly adjusted according to temporary market advantage, thus throwing suppliers into greater competition with each other and intensifying agriproduction systems.

Elaborating the 'oil well' analogy, 'New developments are ongoing for transforming the biomass into a liquid 'biocrude', which can be further refined, used for energy production or sent to a gasifier' (Biofrac, 2006:). The biocrude metaphor naturalises the use and redesign of plants as functional substitutes for fossil fuels, and thus for horizontally integrating agriculture with other industries. The sustainability problem becomes a technical task to access and optimise renewable resources, i.e. decomposable biomass.According to the predecessor of the Biofuels Technology Platform, in the year 2020:

Integrated biorefineries co-producing chemicals, biofuels and other forms of energy will be in full operation. The biorefineries will be characterised, at manufacturing scale, by an efficient integration of various steps, from handling and processing of biomass, fermentation in bioreactors, chemical processing, and final recovery and purification of the product (Biofrac, 2006).

The prospect of second-generation lignocellulosic fuels illustrates how market opportunities frame technical problems. Lignin in plant cell walls impedes their breakdown, thus limiting the use of the whole plant as biomass for various uses including energy. For agricultural, paper and biofuel feedstock systems, 'lignin is considered to be an undesirable polymer' (EPOBIO, 2006) - and so must be redesigned. As NGOs have 
warned, however: 'due to lignin's central role in insect and disease resistance, experimental low-lignin plants have so far been found to be highly susceptible to a variety of fungal diseases' (GFC, 2008).

Some experts have raised doubts about biomass as a general solution for sustainability problems. Whenever second-generation biofuels eventually materialise, their production 'could result in competition between sectors for feedstock', according to an expert report for the UK's relevant Ministry (AEA, 2011: viii). Thus future biofuels may not overcome inter-sectoral competition for biomass and thus resource constraints.

\section{Subsidising scale-up}

Substantial funds have been allocated to R\&D agendas focused on biorefineries under the EU's Framework Programme 7 in the Energy, Environment and Agriculture work programmes. The overall programme has several aims which include: 'enhancing energy efficiency, including by rationalising use and storage of energy; addressing the pressing challenges of security of supply and climate change, whilst increasing the competitiveness of Europe's industries' (DG Research/Energy, 2006).

Substantial funds have therefore been allocated to R\&D agendas focused on novel biofuels under the EU's Framework Programme 7, in both the Energy and Agriculture programmes. Informed by industry's priorities, the EU funded a joint call for proposals on 'Sustainable Biorefineries', initially offering $€ 80 \mathrm{~m}$ total grants. The overall programme has several aims which include: 'enhancing energy efficiency, including by rationalising use and storage of energy; addressing the pressing challenges of security of supply and climate change, whilst increasing the competitiveness of Europe's industries' (DG Research/Energy, 2006).

In these ways, renewable energy is framed as more efficiently linking agriculture with energy for proprietary knowledge in global value chains. The Commission also proposed a large expenditure programme under the 'sustainable bio-energy Europe initiative', likewise favouring liquid fuel processes within diversified biorefineries (CEC, 2009).

As an argument for even more state funds, a successful diversified biorefinery depends on government subsidies for research and development and demonstration (R\&D\&D) plants. According to the European Biofuels Technology Platform, the necessary investment is too costly and commercially risky for the private sector, which therefore requests much more public funds to cover the risks. Testing commercial viability requires an expensive scaleup: 'With an estimated budget of $€ 8$ billion over 10 years, 15-20 demonstration and/or reference plants could be funded' (EBTP, 2010).

This vision has justified allocation of $€ 4.7 \mathrm{bn}$ to the bioeconomy in Horizon 2020, the EU's research framework for 2014-20, as well as diversion of other funds. 'Various funding sources, including private investments, EU rural development or cohesion funds could be utilised to foster the development of sustainable supply chains and facilities' (CEC, 2012). In the first year alone, the R\&D budget for novel biofuels had a budget of $€ 93 \mathrm{~m}$. A new Joint Technology Initiative (JTI) for Bio-Based Industries (BBI) has a budget of $€ 3.8 \mathrm{bn}$, sourcing $€ 1 \mathrm{bn}$ from the Horizon 2020 programme budget and the rest from industrial partners (BBI Consortium, 2014). A substantial proportion has been allocated to biorefineries, which aim at 'Building new value chains based on the development of sustainable biomass collection and supply systems with increased productivity, and 
improved utilisation of biomass feedstock (incl. co- and byproducts), while unlocking utilisation and valorisation of waste and lignocellulosic biomass' (BBI Consortium, 2013)

What prospects for biorefinery innovation to help Europe to 'live within its limits'? (Geoghegan-Quinn, 2012). Although European biorefinery R\&D has explored several designs, some already have become dominant. These decompose biomass relatively more than others, thus consuming more energy and water inputs, as well as generating more pollutants than other potential designs. This pathway gives priority to renewable carbon rather than a low-carbon economy (Nieddu et al., 2012).

A major driver is the search for identical or functional substitutes - 'a strategy which is intended to maintain the existing chemical industry' (ibid.). There are also doubts about energy efficiency of large-scale biorefineries. The lower the effort in collecting and transporting feedstock, the greater the energy return on energy input or investment - a ratio known as EROI. In practical contexts, higher EROI conflicts with operators' economic advantage in economies of scale (Spangenberg and Settele, 2009).

Some NGOs have denounced the Commission for research agendas favouring private interests, e.g. agbiotech, GM trees and conversion techniques. Critics foresee these agendas as promoting the harmful spread of crop monocultures: "promotion of agrofuel production in Latin America for the European market is likely to lead to further expansion of monocultures, destroying natural habitat and replacing small-scale farming systems' (CEO, 2009).

\section{Technofixes: critical perspectives}

68 Sustainability issues about a future bioeconomy, as outlined above, encompass divergent problem-definitions and future visions. Such issues can be illuminated by linking several critical perspectives: socio-technical imaginaries, the techno-fix as a performative device, the rebound effect and capital accumulation by dispossession. Together these help to identify and question socio-political assumptions around biorefineries.

69 When diagnosing societal problems, narratives involve future visions that can be analysed as imaginaries - 'representations of how things might or could or should be'. These imaginaries may be institutionalised and routinised as networks of practices (Fairclough, 2010). Hence an imaginary pre-figures a potential new reality, including an objective and a strategy to operationalise it (ibid.).

70 As a theoretical concept in Science and Technology Studies (STS), sociotechnical imaginaries' are 'collectively imagined forms of social life and social order reflected in the design and fulfilment of nation-specific scientific and/or technological projects' (Jasanoff \& Kim, 2009). Imaginaries either describe attainable futures or prescribe futures that states believe ought to be attained. The concept can help to analyse how 'national S\&T projects encode and reinforce particular conceptions of what a nation stands for' (ibid.).

71 A sociotechnical imaginary includes several aspects: the purposes of S\&T, the public good to be served, participation in steering, by what means, and means to resolve controversies about the pace or direction of R\&D. In this way, sociotechnical imaginaries underlie and drive policies:

Such policies balance distinctive national visions of desirable futures driven by science and technology against fears of either not realizing those futures or causing unintended harm in the pursuit of technological advances. S\&T policies thus 
provide unique sites for exploring the role of political culture and practices in stabilizing particular imaginaries, as well as the resources that must be mobilized to represent technological trajectories as being in the 'national interest' (ibid.). emissions. Amidst controversy over whether conventional biofuels do so, these were portrayed as a transitional phase towards second-generation biofuels. This techno-fix in turn attracted doubts and criticism, though not yet a high-profile controversy. more efficient ways to expand and use domestic biomass for lowering dependence on oil, especially through second-generation biofuels. Debate there has focused on environmental sustainability implications, especially for the US itself. With broader ambitions, the EU imaginary seeks to make biomass a more flexible input for several aims - replacing oil, reducing overall resource burdens, integrating industrial sectors and gaining intellectual property. Towards these aims, converging technologies facilitate biomass decomposability for flexibly extending global value chains (Levidow et al., 2012). EU debate encompasses the broad range of putative societal benefits. Some NGOs question whether the biorefinery agenda serves the public good or private-sector interests, especially in the global South which would supply substantial biomass. have been ineffective in such respects or even extended harm, especially through economic growth (Huesemann \& Huesemann, 2011). Techno-fixes and growth often have been complementary through claims to enhance efficiency, thus attributing resource burdens to inefficiency. Yet this concept always acquires its meaning from specific political-economic aims and so cannot explain difficulties or changes in resource usage. By promising resource-efficiency, a techno-fix can play a self-fulfilling role; it performs, facilitates and naturalizes a specific development pathway, regardless of whether its original expectations are fulfilled.

Its performative role naturalises growth in market demand, while pre-empting alternative societal pathways. In the neoliberal era, the extension of markets has been linked with the technological fix, which 'relies on the coercive powers of competition.' This 'becomes so deeply embedded in entrepreneurial common sense, however, that it becomes a fetish belief that there is a technological fix for each and every problem' (Harvey, 2005).

For a long time, technoscientific advance has been expected to reduce pressure on natural resources. Low productivity is often blamed for food shortages, environmental destruction, and deforestation, as if these were essentially technical problems. Yet the causal relation is often the reverse: technological advance has facilitated efforts to intensify land use, sometimes to the point of large-scale deforestation (Hecht, 2007; also Angleson and Kaimowitz, 2001).

The deforestation example illustrates an apparent paradox which has a long history. With each technological advance towards greater efficiency, optimistic expectations have conflated two different effects: more efficient technology reduces resource usage per unit output, so this improvement will lower overall resource usage. The latter prediction assumes that production serves a finite output, yet this has been repeatedly contradicted by economic growth. For example, after James Watt's steam engine improved the efficiency of earlier designs, England's coal consumption greatly increased, especially as the steam engine provided cheaper energy to a wider range of industries. From that 
outcome, William Stanley Jevons put forward a general proposition that greater technological efficiency in using a resource tends to increase its usage (Jevons, 1866).

Jevons' paradox about greater resource usage has been repeatedly vindicated. The outcome seems paradoxical only if production is understood mainly as fulfilling human needs, or at least a finite demand. Rather, resource usage is driven by financial incentives to supply expanding markets (Polimeni et al., 2009). Likewise economists have studied the rebound effect, whereby more efficient or higher-quality energy has often stimulated greater usage - sometimes even exceeding the efficiency gains, thus contradicting the original aims or claims for resource conservation (Sorrell, 2009). Along those lines, more productive trees both stimulate and accommodate demand, already threatening water resources and soil fertility in US forests. Whenever biorefineries eventually cheapen conversion of non-edible feedstock, the lower cost will plausibly incentivise the expansion of agro-industrial methods, irrigation burdens, etc.

More fundamentally, the private appropriation of natural resources facilitates their greater usage. Technoscientific innovations have been celebrated for greater efficiency, yet this has depended on plunder of human and natural resources, especially in the agroforestry sector. Through such innovations, multinational corporations have a long history of colonizing 'a multitude of new spaces that could not previously be colonized either because the technology or the legal rights were not available' (Paul and Steinbrecher, 2003). Land access has been expanded by formally withdrawing traditional land rights and/or bypassing them through violence. Incentives come partly from ecoefficient innovations which can more easily extract and convert raw materials for biorefineries - both in the past and future.

More generally, capital accumulation has depended upon 'the endless commodification of human and extra-human nature' (Moore, 2010). Further to Jevons' example of the steam engine, its success 'was unthinkable without the vertical frontiers of coal mining and the horizontal frontiers of colonial and white-settler expansion in the long nineteenth century' (ibid.). Cheap or nearly free raw materials have been supplied by cheap labour, which remains the ultimate source of surplus value. Capital-intensive technological innovation increases the organic composition of capital, i.e. the ratio of dead labour to living labour. This reduces the proportion of living labour, thus tendentially limiting surplus value. To overcome this limit, surplus value has generally expanded by appropriating more human and natural resources: 'hence the centrality of the commodity frontier in modern world history, enabling the rapid mobilization, at low cost (and maximal coercion), of epoch-making ecological surpluses' (ibid.).

Industrialization is popularly associated with technological innovation, as if this were the crucial stimulus.

And yet every epoch-making innovation has also marked an audacious revolution in the organization of global space, and not merely in the technics of production.... The revolutionary achievements were made through plunder as much as through productivity. This dialectic of productivity and plunder works so long as there are spaces that new technical regimes can plunder - cheap energy, fertile soil, rich mineral veins (Moore, 2010).

Thus a new 'organization of global space' remains essential for realizing the profitability of technological innovation. For example, African people's secure land tenure impedes global market opportunities for feedstock to supply biorefineries, so this obstacle must be removed (cf. WEF, 2010, cited above). 
83 From this critical perspective on political-economic drivers, more eco-efficient technoscientific innovation depends upon and stimulates plunder. This remains an essential feature of capital accumulation by dispossession (Harvey, 2003). The causality can operate in both directions: opportunities and imperatives for plunder can shape technoscientific innovation. Moreover, future cornucopian expectations justify policy measures to subsidise industry, socialise the cost and privatise the benefits (Block and Keller, 2011). As a promissory device, a techno-fix performs, facilitates, and naturalizes a specific development pathway, while eluding accountability for its beneficent promises. Together the above perspectives help to question, or even contradict, the technooptimistic assumptions of the biorefinery agenda.

\section{Techno-fix for resource constraints?}

An eco-efficient bioeconomy, combining environmental sustainability and economic advantage, has been widely promoted to alleviate resource constraints of rising global demand. An integrated, diversified biorefinery would process various non-food biomass e.g. straw, post-harvest residues in agricultural fields and forests, energy crops grown on 'marginal land', bio-waste, etc. Thanks to future technology, these renewable resources would be converted in more efficient, diverse ways. Horizontal integration across industries - energy, chemicals, transport, etc. - would provide synergies in flexibly selecting and processing resources.

Such putative solutions pre-define the sustainability problem as inefficiency. A technooptimistic cornucopian vision assumes that resource constraints arise mainly from dependence on fossil fuel and/or edible biomass, alongside inefficient techniques for converting alternative biomass sources. Together such assumptions have justified policy measures favouring or creating markets for future techno-fixes. In somewhat different ways, the US and EU have elaborated socio-technical imaginaries promoting such agendas as the public good.

State-industry partnerships seek technoscientific innovation providing input-substitutes for fossil fuels within current infrastructures. As a key priority, 'drop-in fuels' seek exact substitutes for petrol, thus reinforcing the internal combustion engine. Biorefinery R\&D prioritises biomass-decomposition techniques which likewise reinforce current patterns.

This agenda favours economic advantage for the upper parts of the global value chain (e.g. high-value products and proprietary knowledge), drives the lower parts into greater competition to supply cheap biomass and intensifies various burdens on natural resources, especially soil and water. Market incentives favour R\&D on faster-growing, water-demanding trees whose large-scale cultivation would further turn forests into industrial plantations, degrade water quality and aggravate drought problems. In those ways, biorefinery innovation trajectories have the same drivers as previous ones expanding global demand for food, feed, fuel, etc.

Their harmful effects have many historical precedents:

- Eco-efficient techno-fixes have intensified the resource problems that they were meant to alleviate, especially through rebound effects, originally called the Jevons Paradox.

OGlobal space has been reorganised through dispossession (e.g. land grabs, resource 
commoditisation, cheap labour, etc.) as a basis for more resource-efficient technology to become profitable.

Those historical precedents provide grounds to suspect that more efficient, flexible biomass conversion will strengthen financial incentives to intensify resource extraction, especially by industrialising agri-forestry systems. For their economic viability, such techno-fixes depend on cheapening resource supplies without paying their societal and environmental costs. Greater environmental sustainability is conflated with privatesector interests; this agenda socialises risks of R\&D costs, while privatising benefits of consequent products or intellectual property.

In such ways, the sustainability promise of eco-efficient biorefineries naturalises current production-consumption patterns and rising market demand as external objective forces to be accommodated. Techno-fixes play a performative role in reinforcing those patterns, regardless of whether or when future technologies fulfil their promise of greater resource efficiency. Such critical perspectives will be essential for opening up the dominant policy framework to alternative problem-diagnoses and societal futures.

\section{BIBLIOGRAPHIE}

AEA (2011). UK and Global Bioenergy Resource - Final report. Didcot: AEA Technology, report for DECC.

Agostinho F., Ortega E. (2012). Energetic-environmental assessment of a scenario for Brazilian cellulosic ethanol. Journal of Cleaner Production, doi:10.1016/j.jclepro.2012.05.025

Angleson A., Kaimowitz D. (2001). Agricultural Technologies and Deforestation. London, CAB.

BBI Consortium (2013). Strategic Innovation and Research Agenda (SIRA), http://biconsortium.eu

BBI Consortium (2014). Bio-Based Industries Joint Undertaking, http://biconsortium.eu

Biofrac (2006). Biofuels in the European Union: A vision for 2030 and beyond. Final Report of the Biofuels Research Advisory Council (Biofrac).

BioMat Net (2006). 1st International Biorefinery Workshop [website defunct].

Birch K., Calvert K. (2015). Rethinking ‘drop-in’ biofuels: on the political materialities of bioenergy. Science \& Technology Studies, vol. 28, n¹, pp. 52-72.

Block F., Keller M. R. (2011). State of Innovation. Boulder and London: Paradigm Publishers.

Borras S. M. Jr., Franco J. C. (2012). Global land grabbing and trajectories of agrarian change: a preliminary analysis. Journal of Agrarian Change, vol. 12, nº 1, p. 34-59.

Borras S. M. Jr., Franco J. C., Isakson R., Levidow L., Vervest P. (2015). The rise of flex crops and commodities: Causes, conditions and consequences and their implications for research. Journal of Peasant Studies, DOI: 10.1080/03066150.2015.1036417

Carolan M. (2009). A sociological look at biofuels: ethanol in the early decades of the twentieth century and lessons for today. Rural Sociology, vol. 74, n¹, pp. 86-112. 
CEC (2006). Annex to the communication from the Commission. An EU strategy for biofuels - Impact assessment. COM (2006) 34, Brussels, Commission of the European Communities. Commission Staff Working Document, SEC (2006) 142.

CEC (2007). Biofuels progress report: Report on the progress made in the use of biofuels and other renewable fuels in the Member States of the European Union. SEC (2006) 1721.

CEC (2009). Commission Staff Working Document, A Technology Roadmap for the Communication on Investing in Development of Low-Carbon Technologies (SET-Plan), http://re.jrc.ec.europa.eu/ biof/pdf/documents/SEC_2009_1295_Investing_low_car-bon_technologies_roadmap.pdf

CEC (2012). Innovating for Sustainable Growth: A Bioeconomy for Europe. SWD (2012) 11 final.

CEO (2009). Agrofuels and the EU research budget: public funding for private interests. Brussels, Corporate Europe Observatory, http://www.corporateeurope.org/agrofuels/content/2009/05/ agrofuels-and-eu-research-budget

Congressional Budget Office (2010). Using biofuel tax credits to achieve energy and environmental policy goals. Washington, DC, Congressional Budget Office.

Corporate Europe Observatory (2009). Agrofuels and the EU research budget: Public funding for private interests. Brussels, Corporate Europe Observatory. http://www.corporateeurope.org/agrofuels/ content/2009/05/agrofuels-and-eu-research-budget

DCSR (2012). Copenhagen Declaration for a Bioeconomy in Action. Danish Council for Strategic Research, www.eu2012.dk

DG Research/Energy (2006). FP7 Theme 5, Energy. 2007 work programme.

DG Research/Env (2008). FP7 Theme 5, Environment. 2009 work programme.

EPOBIO (2006). Products from plants - The biorefinery future. Outputs from the EPOBIO workshop. Wageningen. May 22-24; Realising the economic potential of sustainable resources: bioproducts from non-food crops (EPOBIO), Final report summary, http://cordis.europa.eu/result/ rcn/47502_en.html

EuropaBio (2007). Biofuels in Europe: EuropaBio position and specific recommendations. Brussels, European Association for Bioindustries, http://www.europabio.org/ Biofuels_EuropaBio_position_Final.pdf.

EBTP (2008). European Biofuels Technology Platform. Strategic Research Agenda \& Strategy Deployment Document, CPL Scientific Publishing. http://www.biofuelstp.eu/ srasdd/080111_sra_sdd_web_res.pdf.

EBTP (2010). Strategic research agenda 2010 update: Innovation driving sustainable biofuels. July. CPL Scientific Publishing, http://www.biofuelstp.eu/sra.html

EC-US Task Force (2009). EC-US Task Force on Biotechnology Research. Proceedings of Workshop on Research for Sustainable Bioenergy, held in February 2008, http://ec.europa.eu/research/ biotechnology/ec-us

EC (2009). Directive 2009/28/EC of the European Parliament and of the Council of 23 April 2009 on the promotion of the use of energy from renewable sources and amending and subsequently repealing Directives 2001/77/EC and 2003/30/EC Renewable Energy Directive. Official Journal of the European Union, L 140, pp. 16-62.

Econexus, Biofuelwatch, Carbon Trade Watch/Transnational Institute, Corporate Europe Observatory, EcoNexus, Ecoropa, Grupo de Reflexión Rural, Munlochy Vigil, NOAH (Friends of the 
Earth Denmark), Rettet den Regenwald, Watch Indonesia (2007). Agrofuels, Towards a Reality Check in Nine Key Areas.

EIA (2015). Direct Federal Financial Interventions and Subsidies in Energy in Fiscal Year 2013. Washington, DC: U.S. Energy Information Administration (EIA), http://www.eia.gov/analysis/ requests/subsidy/

EU Presidency (2007). En Route to the Knowledge-Based Bio-Economy. Cologne, Cologne Summit of the German Presidency.

EuropaBio (2007). Biofuels in Europe: EuropaBio position and specific recommendations.

Fairclough N. (2010). Critical Discourse Analysis: The Critical Study of Language. 2nd edition, London, Pearson.

Franco J., Levidow L., Fig D., Goldfarb L., Hönicke M., Mendonça M. L. (2010). Assumptions in the European Union biofuels policy: Frictions with experiences in Germany, Brazil and Mozambique'. Journal of Peasant Studies, vol. 37, n²4, pp. 661-698.

Garnier E., Bliard E., Nieddu M. (2012). The emergence of doubly green chemistry: a narrative approach. European Review of Industrial Economics and Policy (ERIEP) 4, http://revel.unice.fr/eriep/ index.html?id=3455

Geoghegan-Quinn M. (2010). Commissioner for Research, Innovation and Science, 'Bioeconomy for a better life'. Conference on the 'Knowledge-Based Bio-Economy Towards 2020', Brussels, 14 September.

Geoghegan-Quinn M. (2012). Innovating for sustainable growth: A Bioeconomy for Europe. Press conference, Brussels, 13 February [European Commissioner for Research, Innovation and Science].

Georgia Dept of Natural Resources (2010). Wildlife Resources Division. Public comments to APHIS regarding large proposed field trials of GE eucalyptus trees, http://www.biologicaldiversity.org/ programs/public_lands/forests/pdfs/Georgia_Wildlife_Resources_Div_comments.pdf, http:// globaljusticeecology.org/files/Georgia\%20Wildlife\%20Resources\%20Div\%20comments.pdf GFC (2008). The Real Cost of Agrofuels: Impacts on food, forests, peoples and the climate, Global Forest Coalition.

Gies E. (2010). As ethanol booms, critics warn of environmental effect: Dirty secrets of a "clean" fuel. New York Times, Global Edition. June 25, pp. 15-16. http://www.nytimes.com/2010/06/25/ business/energy-environment/25iht-rbogeth.html?pagewanted=2

GJEP (2012). Analysis of the State of GE Trees and Advanced Bioenergy. Global Justice Ecology Project, http://globaljusticeecology.org/files/Analysis\%20of\%20the\%20State\%20of\%20GE\%20Trees\% 20March\%202012-2.pdf

Harvey D. (2003). The New Imperialism. Oxford, Oxford University Press.

Harvey D. (2005). A Brief History of Neoliberalism. Oxford, Oxford University Press.

Hecht S. (2004). Invisible forests: The political ecology of forest resurgence in El Salvador. In Liberation Ecologies, London: Routledge, ed. R. Preet and M. Watts, pp. 64-104.

Huesemann M., Huesemann J. (2011). Techno-Fix: Why Technology Won't Save Us or the Environment. Philadelphia, New Society.

IEA (2010). Sustainable Production of Second-Generation Biofuels: Potential and perspectives in major economies and developing countries. Paris, International Energy Agency. 
IEA (2014). Bioenergy Task 42 Biorefineries, http://www.iea-bioenergy.task42-biorefineries.com/ en/ieabiorefinery.htm

Jasanoff S., Kim S.-H. (2009). Containing the atom: sociotechnical imaginaries and nuclear power in the United States and South Korea. Minerva, n47, pp. 119-46.

Kamis R., Joshi M. (2008). Biofuel patents are booming. Washington, DC: BakeR\&Daniels.

Levidow L., Birch K., Papaioannou T. (2012). EU agri-innovation policy: Two contending visions of the Knowledge-Based Bio-Economy. Critical Policy Studies, vol. 6, nº 1, pp. 40-65.

Levidow L. (2013). EU criteria for sustainable biofuels: Accounting for carbon, depoliticising plunder. Geoforum, vol. 44, n²1, pp. 211-223.

Levidow L., Paul H. (2011). Global agrofuel crops as contested sustainability, Part II: Eco-efficient techno-fixes? Capitalism Nature Socialism, vol. 22, n², pp. 27-51.

Levidow L., Papaioannou T. (2013). State imaginaries of the public good: Shaping UK innovation priorities for bioenergy. Environmental Science and Policy, vol. 30, n¹, pp. 36-49, http:// dx.doi.org/10.1016/j.envsci.2012.10.008

Levidow L., Birch K., Papaioannou T. (2013a). Divergent paradigms of European agro-food innovation: The Knowledge-Based Bio-Economy (KBBE) as an R\&D agenda. Science, Technology and Human Values, vol. 38, n²1, pp. 94-125.

Levidow L., Papaioannou T., Borda-Rodriguez A. (2013b). Path-dependent UK bioenergy. In symposium on Energy Transitions, Science as Culture, vol. 22, n² , pp. 196-204.

Liska A. J., Haishun Y., Maribeth M., Steve G., Humberto B.-C., Matthew P.P. (2014). Biofuels from crop residue can reduce soil carbon and increase $\mathrm{CO} 2$ emissions. Nature Climate Change, $\mathrm{n}^{\circ} 4$, pp. 398-401, doi:10.1038/nclimate2187

Martin J. (2010). The Billion Gallon Challenge: Getting biofuels back on track. Washington, DC: Union of Concerned Scientists.

Martin J. (2014). New Poet-DSM biofuels plant a sign of things to come. 16 September, http:// www.ucsusa.org/news/commentary/new-poet-dsm-cellulosic-biofuelplant-0434.html\#.VPiQbXysXZU

Martinelli L. A., Filoso S. (2008). Expansion of sugarcane ethanol production in Brazil: environmental and social challenges. Ecological Applications, vol. 18, n 4, pp. 885-898.

Melamu R., Blottnitz H. (2011). 2nd Generation biofuels a sure bet? A life cycle assessment of how things could go wrong. Journal of Cleaner Production, $n^{\circ} 19$, pp. 138-144.

Moen M. (2009). Building a market for a byproduct of corn-based ethanol. The Whole Kernel, Winter, http://www.cfans.umn.edu/Solutions/Winter2009/WholeKernel/index.htm

Moore J. ( 2010). The end of the road? Agricultural revolutions on the capitalist world-ecology, 1450-2010. Journal of Agricultural Change, vol. 10, n³, pp. 389-413.

Murphy A.M., van Moorsel D., Ching M. (2007). Agricultural biotechnology to 2030: Steady progress on agricultural biotechnology. Paris, OECD.

NABC (2000). The Biobased Economy of the 21st Century: Agriculture Expanding into Health, Energy, Chemicals, and Materials. Ithaca, NY, North American Agricultural Biotechnology Council (NABC), http://nabc.cals.cornell.edu/Publications/Reports/pubs_reports_12.htm

Nieddu M. et al. (2012). Green Chemistry: towards a sector-based approach for sustainable development? 
Nieddu M. Vivien F.-D. (2012). La « chimie verte » : vers un ancrage sectoriel des questions de développement durable?, Economie appliquée, LXV(2), pp. 169-193.

Nuffield Council for Bioethics (2009). New approaches to biofuels: Ethical issues. Public consultation, http://www.nuffieldbioethics.org/biofuels.

Nuffield Council for Bioethics (2011). Biofuels: Ethical Issues.

Olmstead J. (2009). Fueling Resistance? Antibiotics in Ethanol Production, IATP, http:// www.iatp.org/files/258_2_106420.pdf

Olmstead J. (2012). Bugs in the System: How the FDA Fails to Regulate Antibiotics in Ethanol Production, IATP, http://www.iatp.org/files/2012_05_02_AntibioticsInEthanol_JO_0.pdf

Paul H. Steinbrecher R. (2003). Hungry Corporations: Transnational biotech companies colonize the food chain. London, Zed.

Polimeni J.M., K., Mayumi M., Giampietro Alcott. B. (2009). The Myth of Resource Efficiency. London, Earthscan.

Searchinger T., Heimlich R., Houghton R.A., Dong F., Elobeid A., Fabiosa J., Tokgoz S., Hayes D., $\mathrm{Yu}$ T.H. (2008). Use of U.S. cropland for biofuels increases greenhouse gases through emissions from land-use change. Science, vol. 319, n5867, pp. 1238-1240. <http://www.ncbi.nlm.nih.gov/ pubmed/18258860>, <http://www.scienceexpress.org>

Smolker R. (2008). The new bioeconomy and the future of agriculture. Development, vol. $51, \mathrm{n}^{\circ} 4$, pp. 519-526.

Söderberga C., Eckerberg K. (2013). Forest land use and conflict management: global issues and lessons learned. Forest Policy and Economics, n 33, pp. 112-119.

Sorrell S. (2009). Jevon's paradox revisited: The evidence for backfire from improved energy efficiency. Energy Policy, n³7, pp. 1456-1469.

Spangenberg J.H. Settele J. (2009). Neither climate protection nor energy security: biofuels for biofools? Uluslararası İlişkiler, vol. 5, n²0, pp. 89-108, http://www.uidergisi.com/wp-content/ uploads/2011/06/Neither-Climate-Protection-nor-Energy-Security.pdf

Thompson P.B. (2008). Agricultural biofuels: two ethical issues. Reshaping American Agriculture to Meet its Biofuel and Biopolymer Roles, Ithaca, NY, NABC Report 20, pp.145-54, http:// nabc.cals.cornell.edu/Publications/Reports/nabc_20/20_5_1_Thompson.pdf Tokar B. (2010). Biofuels and the global food crisis. In Magdoff F. and Tokar B. (eds.), Agriculture and Food in Crisis: Conflict, resistance and renewal, New York, Monthly Review Press, pp. 121-138.

TU-E/NWO (2015). Biofuels and (Ir)responsible Innovation. Conference report, Eindhoven University of Technology (TU-E) \& Netherlands Organization for Scientific Research (NWO), 13-14 April, http://www.biobasedeconomy.nl/wp-content/uploads/2015/07/Romijn-et-al-April-2015biofuels-conference-report.pdf

UNEP (2011). The Bioenergy and Water Nexus. United Nations Environment Programme (UNEP), Oeko-Institut and IEA Bioenergy Task 43.

US DoE n.d. Bioenergy. Office of Science, Genomic Science Program, Systems Biology for Energy and Environment, US Department of Energy. http://www.genomicscience.energy.gov/biofuels/ index.shtml\#page=news

US DoE (2006). Breaking the Biological Barriers to Cellulosic Ethanol:A Joint Research Agenda. http:// www.doegenomestolife.org/biofuels/2005workshop/b2blowres63006.pdf 
US DoE (2015). Lignocellulosic Biomass for Advanced Biofuels and Bioproducts Workshop Report. http:// www.genomicscience.energy.gov/biofuels/lignocellulose/BioenergyReport-

February-20-2015LR.pdf

US NAS (2007). National Academies of Science. Water Implications of Biofuel Production in the United States. Washington, DC, National Academies Press. http://www.nap.edu/catalog/12039.html

USDA Final Environmental Assessment (2010). Appendix III. USDA Forest Service assessment of impacts on hydrology.

USFS (2011). Forest Service unveils first comprehensive forecast on southern forests. US Forest Service, http://www.srs.fs.usda.gov/news/472

WEF (2010). The Future of Industrial Biorefineries. Geneva, World Economic Forum, www.weforum.org

\section{RÉSUMÉS}

An eco-efficient bioeconomy has been widely promoted to alleviate resource constraints of rising global demand. An integrated, diversified biorefinery would convert diverse non-food biomass into valuable products, thus providing input-substitutes for fossil fuels within current infrastructures. This agenda intensifies various resource burdens and market competition to supply cheap biomass. Biorefinery innovation trajectories have the same drivers as the current production-consumption patterns expanding global demand for food, feed, fuel, etc. More efficient, flexible conversion of biomass will strengthen financial incentives to intensify resource extraction, especially by industrialising agri-forestry systems. Such a techno-fix depends on cheapening resource supplies without paying for their societal and environmental costs.

\section{INDEX}

Keywords : integrated, diversified biorefinery, resource constraints, techno-fix; eco-efficient technology

Code JEL Q2 - Renewable Resources and Conservation, Q42 - Alternative Energy Sources

\section{AUTEUR}

\section{LES LEVIDOW}

Open University, L.Levidow@open.ac.uk 